\title{
New Polymeric Potentiometric Coated Wire Sensors for Determination of Montelukast Sodium in Commercial Products
}

\author{
Salma Ali Al-Tamimi , Nawal Ahmed Alarfaj, Alaa Abdulgafour Turkistani \\ Department of Chemistry, College of Science, King Saud University, P. O. Box 22452, Riyadh 11495, \\ Saudi Arabia \\ *E-mail: satamimi@ksu.edu.sa
}

doi: $10.20964 / 2021.06 .43$

Received: 3 March 2021 / Accepted: 12 April 2021 / Published: 30 April 2021

\begin{abstract}
Herein the study concerns with the construction of new potentiometric coated wire sensors by incorporating the montelukast sodium (MON) with phosphomolybdic (PMA) and phosphotungstic acids (PTA). The formed ion-pair complexes MON-PM, MON-PT and MON-PM/PT was utilized to analyze MON in commercial products. After optimizing the method parameters, the linearity between the potential $/ \mathrm{mV}$ and $-\log [\mathrm{MON}]$ of the suggested sensors were obtained in the range of $1.0 \times 10^{-8}-1.0 \times 10^{-2}$, $1.0 \times 10^{-8}-1.0 \times 10^{-3}$ and $1.0 \times 10^{-9}-1.0 \times 10^{-2} \mathrm{~mol} \mathrm{~L}^{-1}$ for the designed MON-PM, MON-PT and MON$\mathrm{PM} / \mathrm{PT}$ sensors, respectively. The derived linear equations were found to be $\mathrm{E}_{(\mathrm{mV})}=(58.21 \pm 0.5) \log$ $[\mathrm{MON}]+641.79, \mathrm{E}_{(\mathrm{mV})}=(57.37 \pm 0.5) \log [\mathrm{MON}]+670.54$ and $\mathrm{E}_{(\mathrm{mV})}=(58.82 \pm 0.5) \log [\mathrm{MON}]+$ 714.14, with correlation coefficients $0.9997,0.9998$ and 0.9998 for the three sensors respectively. The content uniformity assay was carried out to ensure the quality control of tablets. To evaluate also the validity of the suggested sensors, accuracy, precision, linearity, robustness and ruggedness were studied. The proposed potentiometric technique can be exploited in the determination of MON in its pure and commercial products.
\end{abstract}

Keywords: Montelukast Sodium, Potentiometric analysis, Mixed ion-associate, Phosphomolybdic/phosphotungstic, Commercial products

\section{$\underline{\text { FULL TEXT }}$}

(C) 2021 The Authors. Published by ESG (www.electrochemsci.org). This article is an open access article distributed under the terms and conditions of the Creative Commons Attribution license (http://creativecommons.org/licenses/by/4.0/). 